\title{
Optimising Fund Management of Mosque Cash for Economic Empowerment of People.
}

\author{
Sri Wulandari, Tjiptohadi Sawarjuwono, Sri Iswati \\ Postgraduate School \\ Universitas Airlangga \\ Surabaya, Indonesia \\ sriwulandari2710@gmail.com \\ tjiptohadi@feb.unair.ac.id \\ iswati.feua@gmail.com
}

\begin{abstract}
The large Muslim population in Indonesia is directly proportional to the number of mosques that it has. The large population of mosques scattered throughout Indonesia should be able to contribute to the prosperity of society if we return the function of the mosque to as it was in the time of the Prophet. Today, we often see there are still mosques that allocate cash funds only for the construction and physical improvement of the mosque, whereas on the other hand, there are still pilgrims who are at a low economic level. This shows that there is still lack of optimal management of cash in mosques. With the management of the mosque cash funds optimally in relation to social orientation, it will be able to help improve the economic empowerment of the people. For example, the mosques' cash funds are used to provide assistance in the form of free skills training so that it will increase the independence of the people, and providing working capital assistance program to the people who have difficulty in getting funding to open a business. The discussion in this paper is to optimise the use of mosque cash funds through programs or activities in the form of services in areas of worship, education, health, and society. This will be able to restore the function of the mosque as in the time of the Prophet as a centre of community activity and to help the economic empowerment of the people to help overcome the problem of poverty in Indonesia.
\end{abstract}

Keywords: Cash funds mosque, Poverty, Economic Empowerment.

\section{INTRODUCTION}

Indonesia is a country with a predominantly Muslim population. The Muslim population amounted to 207.1276.162 people or equal to $87.18 \%$ of the total population of Indonesia, which amounted to 237,641,326 inhabitants in 2016 (Central Statistic Agency, 2016).

This large number of Muslims is directly proportional to the number of places of worship owned. In 2016, the number of mosques in Indonesia was 206,024 buildings, with the following details: the number of mosques totalled 30, Great Mosques totalled 3.856, the historic Mosques totalled 752, the grand mosques totalled 359, the jamboras totalled 173.222, and mosques in public places totalled 28800 (Mosque information system, 2016).

The large number of mosques scattered throughout Indonesia indicates that the mosque can contribute greatly in the prosperity of the community if we restore the function of the mosque to as in the time of the Prophet, both in terms of fundraising, the utilisation of funds for economic empowerment of the Ummah and in terms of the provision of facilities.

The more complex problems of society demand the mosque be the centre of civilization as it can accommodate social needs. Currently there is a shift in the role and function of the mosque so that the mosque is only used as a means of worship - mahdhah. The crisis of the role of the mosque needs to be reviewed again. It is time that the mosque was reconstructed as a modern religious institution equipped with facilities that can empower the people. Therefore there is the need for good management. Good mosque management is supported by good financial management. Various planned programs cannot be expected if they are not supported by good financial management and professionalism. This is because most of the funds collected in the mosque are donation funds or infaq from pilgrims. Mosque funds that have been collected should be able to be used for the economic empowerment of the people around the mosque.

Many mosques are still only allocating funds for the construction and physical repair of the mosque. On the other hand, there are many pilgrims who are still in poor economic conditions. In a study conducted in the Special Region of Yogyakarta in 2013, the idle mosque fund is estimated to amount to about $\mathrm{Rp} 300,000,000,000$. This proves that the financial management of the mosque is still not optimally used for da'wah activities or productive programs (Adnan, 2013:129).

If the financial allocation of mosque cash all over Indonesia can be done effectively, then there can be economic empowerment of the Ummah. This can help the government programs in improving people's welfare. With the optimal allocation of mosque cash funds, it is expected to help the poor and reduce the number of poor people in Indonesia.

\section{LITERATURE RIVIEW}

\section{A. Mosque In Islamic History}

Mosque comes from the word sajada-sujudan, which means obedient, and submissive with respect and reverence, or a place of prostration. (Ayub, 1996:01). 
At the beginning of the Islamic propagation process of the Madinah period, when the Prophet emigrated, the first place built was the Quba mosque. The Quba Mosque was built by way of mutual help by the community and for the benefit of society in order to practice the teachings of Islam. In the Qur'an Surat At-Taubah, verse 108:

"Surely a mosque founded on the basis of taqwa (Quba mosque), since the first day is more worthy of your prayers in it. Inside there are people who want to purify themselves. And Allah loves those who are pure "(Q.S al-Taubah: 108)

After the construction of the Quba mosque, Rasulullah SAW continued his journey to Madinah, where the first thing he did was to build a mosque. This was later called the Nabawi mosque. In this mosque, Rasulullah SAW fostered Islamic society, which began by fostering a community that was multi-race, multi ethnic, and multi-religious. The Islamic community that was built by the Prophet succeeded so well that they became a people who were admired by friends and opponents, and became the world leaders of their time.

The function of the mosque of Nabawi at the time of the Prophet SAW, can be described as follows: (Muslim, 2004:109)

1. To perform worship mahdhah and sunnah prayers that are incidental

2. The centre of Islamic education and teaching.

Rasulullah SAW often received revelation in the mosque of Medina, and taught it to the Companions in various things such as law, society, legislation and various other teachings. The Companions of the Prophet performed various scientific activities in the mosque, including studying and discussing the sources of Islamic teachings. The mosque of Medina also provides a special place for those who specialise in his activities to deepen the knowledge of religion which is called ahl al-Shuffah.

3. As an information centre of Islam.

Rasulullah SAW conveyed various kinds of information in the mosque including making it a place to ask for friends.

4. As a place to resolve cases and disputes, to solve legal and judicial problems and to become the centre of solving various problems that occur in society.

5. As the centre of economic activity.

In this case, the mosque is not meant to be used as a trade centre or industry, but as a centre for generating Islamic ideas and an economic system, which generates prosperity and the equitable distribution of income for mankind in a fair and balanced way.

6. As the centre of social and political activities.

Social activities cannot be separated from the mosque as a gathering place for the jama'ah in various layers of society. From the atmosphere there, there is mutual social interaction and mutual love. Political activity is also inseparable from the life of the mosque, because politics and human life is a unity that cannot be separated. The politics developed here are high-level politics that are Islamic rather than dirty politics that harm society groups.

\section{B. Financial Management Of Mosque}

Mosques require a fee that is not small each month to run. The costs incurred fund routine activities. Caring for mosques and carrying out mosque activities is only possible if the funds are available in sufficient quantities. Without knowing the funds, almost all ideas that seek to prosper in the mosque cannot be implemented. Mosque managers are required to think of a way out to present funds either in cash, or building materials (Ayub, 2007:7).

After the construction of the mosque is prepared, the following rare important note is the calculation of funds. Before the mosque fund raising activities are carried out, it is necessary to stipulate the following matters: (Ayub, 2007:61)

1. Funds of any kind to be collected. Sources of funds can be obtained from zakat, waqaf, characters, alms, donations, aid, and so forth.

2. Whoever is the collecting officer(s).

3. The fund collection period is for a year.

4. Where is the collection point?

5. Collection and execution.

6. In the collection of these funds, cleverness and the kelincaha board or committee is a very decisive factor.

Countermeasures on the costs incurred are the responsibility of the board, to do with pilgrims. The active board is not enough. From the pilgrims, it is expected that keaktifannya will help ease the financial burden of the mosque. Fundraising should be done in a good way, so that the pilgrims want to donate their property with full sincerity and awareness. The mosque's approach to the congregation should be persuasive. In addition to this approach, the mosque board is also expected to provide clear information about the activities to be implemented. The trust of pilgrims usually grows because of active management. With a convincing management, pilgrims will not hesitate to raise funds sincerely (Ayub, 2007:62).

\section{Efforts to Prosper the Mosque}

The spirit of the people to want to build a mosque seems very high. They do not hesitate to sacrifice time, energy, thought and money. Unfortunately, seteah mosque stands to be prosperity only when building it. The mosque is only crowded at Friday prayer time and tarawih. Though a mosque that is not prosperous cannot do menajalankan functions properly (Ayub, 2007:72).

The prosperous mosque is a mosque that grows in to the central dynamics of the ummah. It serves as a place of worship and the centre of Islamic culture in a broad sense. It is the duty and responsibility of all Islamic people to help the mosque prosper that they founded in society. Some of the following 
efforts, if implemented, can be expected to help increase the prosperity of the mosque such as: (Ayub, 2007:62)
1. Development activities
2. Activities of worship
3. Religious activities
4. Educational activities

\section{Empowerment Of People In Economy}

According to the Central Bureau of Statistics, the number of poor people (population with a per capita expenditure per month below the poverty line) in 2016 reached 28.01 million people or $10.86 \%$ of the total population of Indonesia (Badan Pusat Statistik: 2016). The large number of poor people is one of the problems associated with fulfilling basic human rights.

Poverty in Islam is also regarded as something to be fought, because poverty is a grave danger to mankind and only a few people fall into civilization simply because of piety alone. Fidelity sometimes encourages a person to commit acts that are forbidden by their religion. This is in accordance with the words of the prophet that read: (Qadir, 2001:24)

"Almost all the piety will be kufr and almost hasad precedes fate" (Syaikh Al-Abani).

One way to cope with poverty is with the support of people who are able to spend their wealth and help those in need. Such assistance should not only be consumptive, but also it must be productive so that it will have a more permanent result. By actively doing economic empowerment, this will be able to improve society prosperity.

According to Jim Ife, empowerment is a provider of resources, opportunities, knowledge, and skills for people to improve their capacity, so they can discover a better future. According to Gunawan Sumohadiningrat, empowerment is an effort to build the power possessed (dhuafa) by encouraging others to raise motivation and awareness about the potential of their own, and to strive to develop it (Sumahadiningrat, 1997:165).

Economic empowerment has been practiced by the Prophet and the caliphs of his time with the aim of reaching falah, which is welfare that not only fulfils the needs of the human body but also their spiritual needs. In an effort to reach falah demands, an instrument to make it happen is needed. An economic empowerment strategy is one of the instruments needed to improve the people's economy.

The purpose of the empowerment of the people is prosperity. Welfare means a condition for the fulfilment of the needs of a person or a community from a source that can be obtained by the person concerned. A prosperous society can be interpreted as all of its needs being met by various sources that exist in the environment.

The empowerment of people in the economic field has the potential to be done by mosques because the mosque funds have an average surplus per month. Mosques should not just be a symbol of Muslim ritual, but more than that, the mosque can be one important component in community empowerment.

\section{RESEARCH METHOD}

This research study used a descriptive qualitative approach with a literature research study method. Literature studies look for reference to theories that are relevant to the case or problems found. Library research is done by reviewing the ideas of experts in books, journals, and research report articles. This study used the Qur'an and hadith as the main sources and some external literature such as books and previous research journals.

\section{RESULT \& DISCUSSION}

If we look at the time of the Prophet Muhammad, then we can find how the Prophet managed the mosque so that the mosque could contribute to the welfare of the people. Prophet Muhammad SAW taught that the mosque not only functions as a centre of worship but also serves as a place of education and teaching, as an Islamic information centre, economic centre, a centre for social and political activities and a centre for da'wah activities for Muslims. Therefore, the mosque plays a major role for the people in changing the values of life in the practice of religion and community development through social and economic piety programs.

The scope of financial management is to create guidelines that include collection, channelling, and fund balances. In the fund-raising, it should be clear as to the type of funds needed and how the funds are received. Some types of funds are obtained through zakat, infaq, alms, wills, inheritance, kafarat, waqf, and grants. The way the receipt of funds is managed should be noted also, which can be through a bank account, received directly in the mosque or going directly to the fund-needer (Mufraini, 2006:134).

In relation to the distribution of funds, it should be noted who is entitled to receive the funds, and for what purpose, whether it is used for activities that are consumptive or used for productive activities. In the expenditure of funds, one must also pay attention to the users of these funds, because the purpose of channelling funds is for the empowerment of the people in order to create prosperity.

Indonesia, which is a Muslim majority country, has 206,024 mosque buildings scattered throughout the territory of Indonesia. If the function of the mosque is optimised as in the time of the Prophet, then the mosque will be able to contribute to improving the welfare of the people, especially around mosque.

One example of a mosque that has implemented its function of economic empowerment is Fatimatuzzahra Grendeng Purwokerto Mosque. Fatimatuzzahra Mosque established the Mafaza Polyclinic in 2002, and provided free health care to the community. In addition to the health sector, 
Fatimatuzzahra Mosque also contributes in the field of education by making learning programs for outstanding students, skills training, and TPQ. In the economic field, the Fatimatuzzahra Mosque has created entrepreneurship training programs, donated to victims of natural disasters, as well as assisted the poor. All of the programs show that the mosque is not only used as a sacred place to worship, but that the mosque can also plays an active role in various fields, especially in the empowerment of the people (Sochimin, 2015:116).

The achievements of the Fatimatuzzahra mosque are a testament to the successful workings of a good management system. In this case, the mosque also put the auditors in a position in the management of the mosque so that public trust in the institution of the mosque can be maintained. They make the mosque's budget transparent to the public through reports every Friday, and in bulletins and magazines published every two months.

Another example of a mosque that has implemented its function of economic empowerment is the Jogokariyan Mosque. The Jogokariyan Mosque is located in the village of Jogokariyan, in Daerah Istimewa Yogyakarta. Here, the potential data of jama'ah is best utilised. All of the needs of the Jogokariyan mosque can be provided to jama'ah for pilgrims (Masjidjogokariyan. 2016).

Jogokariyan mosque leaders have a different financial system to other mosques. If there is a mosque announcing proudly that their balance of infaknya is in millions, then Jogokariyan always strives for when diumumka, that the infak balance is as close to zero rupiah as possible. They have the thought that the infak is a reward for deeds of shalih, and is not to be stored in bank accounts.

The Jogokariyan Mosque also has an independent congregation movement. The total cost for the year is 52, so the cost will be earned per week. It is then divided by the capacity of the mosque, and there is a cost per place of prayer. The results are then socialised. The congregation will be informed that if in one week they are included in that number, then he is an independent congregation, but if it happens more, then he is a congregation member subsidy, if it is less then he is a pilgrim who will receive a subsidy. The movement managed to raise the mosque's infak, because people would be embarrassed if their worship was subsidised.

In addition, the Jogokariyan mosque also has scenario planning to do with advancing da'wah. Among the plans are improving the religious quality of society, familiarising the community with the mosque, increasing welfare jama'ah through mosque barns, multiplying services such as opening polyclinics, besiswa aid and providing capital assistance business services.

The two mosques mentioned are an example of effective mosque management having a positive effect on the economic empowerment of the people. The development of a socialoriented mosque cash fund will have an impact on the creation of the economic empowerment process, and can improve the economic capacity of the community. Opportunities that will emerge include the creation of employment opportunities, creating a program to encourage independence or providing charity assistance.

The management of the mosque's cash funds optimally, not only for the physical construction of the mosque and not allowing the mosque's cash to be piled up, would be more beneficial. The mosque's cash should be used for things that are more productive and beneficial to the ummah. This will be able to help improve the welfare of the people, especially the community around the mosque.

\section{CONCLUSION}

Mosques should not just be a symbol of Muslim rituals, but more than that, the mosque can be one important component of community empowerment, including in the economic field. The utilisation of mosque cash for things that are more productive and beneficial to the ummah will be able to help them to improve the welfare of people, especially the poor communities around the mosque.

Mosque administrators should be able to make the mosque as a tower of the resurrection of the ummah, so that it not only focuses on the magnificent physical building as a measure of the success of the mosque management in advancing the mosque. A mosque administrator should be able to restore the function of mosques in helping jama'ah solve the problems of life, so that the ideal function of the mosque can be realised to the fullest.

The development of a social-oriented mosque cash fund will have an impact on the creation of the economic empowerment process, and can improve the economic capacity of the community. Opportunities that will emerge include the creation of employment opportunities, creating a program for independence or providing charity assistance.

\section{ACKNOWLEDGMENT}

Thanks to Prof. Dr. H. Muslich Anshori, S.E., M.Sc., Ak., CA and Dr. Sri Herianingrum SE, M.SEi for the valuable suggestions which made this research study finish successfully up to the publication.

\section{REFERENCES}

[1] Adnan, M.A, "An Investigation of the Financial Management Practices of the Mosques In The Special Region of Yogyakarta Province, Indonesia", 2013, Germany: Sharia Economics Conference.

[2] Ayub, Moh. E, dkk., Manajemen Masjid, 1996, Jakarta: Gema Insani Press

[3] Badan Pusat Statistik. 2016. Penghitungan dan Analisis Kemiskinan Makro Indonesia 
[4] Departemen Agama Republik Indonesia. 1998. Al-Qur'an dan Terjemahannya dengan Transliterasi. Semarang: PT. Karya Toha Putra

[5] Masjidjogokariyan. 2016. Sejarah Masjid Jogokariyan

[6] Mufraini, M. Arif, Akuntansi dan Manajemen Zakat: Mengomunikasikan Kesadaran dan Membangun Jaringan, 2006, Jakarta: Kencana.

[7] Muslim, Aziz, Manajemen Pengelola Masjid, 2004, Jurnal Aplikasi Ilmu-Ilmu Agama, Vol V, No 2

[8] Nainggalon, Pahala, Manajemen Keuangan Lembaga Nirlaba, 2012, Jakarta: Yayasan Bina Integrasi Edukasi.
[9] Sistem Infomasi Masjid. 2016. Daftar Jumlah Masjid.

[10] Sumahadiningrat, Gunawan Pembangunan Daerah dan Pengembangan Masyarakat, 1996, Jakarta: Bina Rena Pariwara.

[11] Sochimin, Praktik Manajemen Keuangan Masjid Berbasis Pemberdayaan Ekonomi Umat di Kota Purwokerto, 2012, IAIN Purwolerto.

[12] Qadir, Abdurrahman, Zakat (Dalam Dimensi Mahdah dan Sosial), 2001, Jakarta: Raja Grafindo. 